AFRICAN

\title{
Which lodestar to follow? South African public opinion on China and other international partners*
}

\author{
by Floor Keuleers
}

Leuven International and European Studies (LINES)

KU Leuven (University of Leuven)

\begin{abstract}
South Africa's international orientation is said to be shifting, with the post-1994 focus on democracy and human rights increasingly complemented or even replaced by pragmatic relations with fellow BRICS countries. This article asks how ordinary South Africans perceive the different international partners their country might turn to, with a specific focus on China. It analyses the 2015 wave of the Afrobarometer Survey, which uses nationally representative samples to grasp the views of citizens across the continent. The article is structured around three questions. 1) How is China's engagement with South Africa seen by South Africans? 2) How do South African evaluations of China measure up to their views of other development partners, both 'old' and 'new'? 3) And how does this compare to views in other African countries? The article also brings South Africa's internal dynamics into the equation, looking at patterns of age, race, and political affiliation.
\end{abstract}

* This research was made possible by a PhD Fellowship from the Research Foundation Flanders (FWO). 
AFRICAN

EAST-ASIAN

AFFAIRS

\section{Introduction}

South Africa's approach to foreign policy is said to be in flux, reflecting the broader dynamics of change in Africa's international relations. On the one hand, the legacy of the Mandela years entails that the country is still strongly associated with the defence of Western-style democracy and human rights, both domestically and in international affairs (Anthony, Tembe, \& Gull, 2015; Van der Westhuizen \& Smith, 2015). At the same time, however, there appears to be a significant shift in South Africa's orientation towards its fellow 'emerging countries' of the global South, who embody and espouse a different approach to both development and development cooperation (Bradley, 2016; Landsberg, 2014). South Africa joined the BRIC(S) format in 2010, the same year that it established a 'comprehensive strategic partnership' with China. The country's 2011 White Paper on foreign policy singled out South-South solidarity as one of two central tenets of its international engagement, the other being Pan-Africanism (Department of International Relations and Cooperation, 2011). The ruling African National Congress (ANC) in particular has voiced strongly China-oriented positions, stating that 'China['s] economic development trajectory remains a leading example of the triumph of humanity over adversity' and that 'the exemplary role of the collective leadership of the Communist Party of China in this regard should be a guiding lodestar of our own struggle' (African National Congress, 2015). South Africa's relationship with China has not been without obstacles, with the South African leadership publicly questioning its sustainability and with domestic concerns rising over perceived neocolonial influence (Bradley, 2016).

It is not surprising, therefore, that these shifting orientations have led to questions regarding South Africa's future positioning in international affairs as well as the development model it is to apply at home. What is striking is the relative scarcity of information on how this reorientation is seen by broader sections of South African society. How do ordinary South Africans perceive the different international partners courting their country and continent? Rather than standing at the side-line of elitelevel debates, South African public opinion can be understood as one of the arenas in which a competition of models is taking place. China in particular has recognised 


\section{AFRICAN \\ EAST-ASIAN \\ AFFAIRS

this, rolling out an impressive array of public diplomacy initiatives in the country over recent years (Hartig, 2014; King, 2013; Wasserman, 2015; Wu, 2012).

This article analyses the last wave of the Afrobarometer survey to answer three core questions. First, how is China's engagement with South Africa seen by South African public opinion? Second, how do South African evaluations of China measure up to their views of other development partners, both 'old' and 'new'? And finally, how does the South African perception compare to the way China is perceived in other African countries? In formulating an answer to these three questions, the article also seeks to bring South Africa's internal dynamics into the equation. Instead of regarding the country's public opinion as a monolith, it looks at both differences and convergences in opinion between various societal groups.

The article is structured as follows. The next section summarises the existing literature on South African public opinion regarding international relations and foreign policy. The second part of the article discusses the survey data that is used in the analysis, focusing particularly on the sampling procedures used by the Afrobarometer. The third section presents the findings, structured along the key comparisons outlined above. The final section concludes and discusses potential avenues for future research.

\section{South African public opinion on international relations}

The literature on South African public opinion regarding foreign policy and international relations is still a very limited one. The main reason for this is that 'the assumption is still that South Africans, like most publics around the world, are illinformed and uninterested in international issues' (Van der Westhuizen \& Smith, 2015:319). At the same time, however, the argument has been made that 'public opinion' only comes into existence precisely in the process of being studied, as members of the public are explicitly invited to express their opinion (Nel, 1999). In this view, it is a very welcome development that more studies are becoming available on how South Africans regard key issues in their country's international affairs. 
AFRICAN

EAST-ASIAN

AFFAIRS

The first comprehensive study of South African public opinion on foreign policy issues was conducted in 1997-8 (Nel, 1999). As this study took place before China's activities in Africa increased exponentially and became a topic of major debate, China does not feature prominently in the questions that were asked. The study did, however, ask respondents about two well-known cases of foreign policy at the time, one of which was the 1996 decision by Nelson Mandela to end ties with the Republic of China (ROC) and commence a diplomatic relationship with the People's Republic of China (PRC) instead. The study found that 43 per cent of respondents found this to be the right decision; 33 per cent rejected it; 22 per cent could not make up their minds; and 0.7 per cent indicated they had not heard of the ROC-PRC issue. Opinions varied strongly over different groups, with race and political affiliation emerging as key structuring variables (Nel, 1999: 141-142).

A follow-up study was undertaken some 15 years later, in the autumn of 2012 (Van der Westhuizen \& Smith, 2015). This survey focused on public attitudes regarding three core questions: what should be the goals of South African foreign policy, what should South Africa's international role look like, and who should be the key allies and role models of the country. It is especially in the latter part that attitudes on China came to the fore. It was found that a majority of South Africans (56 per cent) view China as a more important trading partner than the United States of America (USA) or Europe, with few differences between demographic groups. China also emerged on top when respondents were asked 'With which country or group of countries in the list should South Africa be seen to be an ally or close friend?'. China was chosen by 26 per cent of respondents, scoring better than the USA (19 per cent) and Europe (15 per cent). China was also selected most often by respondents ( 26 per cent) as the country that South Africa can learn from most about reducing poverty and unemployment. It did not score well, however, when respondents were asked in which country or region other than South Africa they would prefer to live, coming in behind Southern Africa, the USA, and Europe.

The last representative study was conducted in 2013 by the Human Sciences Research Council, which surveyed 2,739 South Africans to gauge their interest in foreign affairs, knowledge of world events, and foreign policy preferences (Roberts, 


\section{AFRICAN \\ EAST-ASIAN \\ AFFAIRS

Struwig, Gordon, \& Bohler-Muller, 2015). This specific study did not include questions on China.

Finally, a number of studies are available that focus specifically on (South) African views of China, but most of these were not based on a representative sample. Sautman and Hairong published a study in 2009 with data collected from students and university faculty in nine African countries, including South Africa (Sautman \& Yan, 2009). Yoon Jung Park published a study on perceptions of the Chinese in South Africa and Lesotho, based on ethnographic interviews between 2008-2010 and surveys with a non-random targeted sample (Park, 2013). Hanusch and Keuleers have used Round 4 Afrobarometer data to make a cross-country analysis of African perceptions of China's help to African countries, including South Africa (Hanusch, 2012; Keuleers, 2015). Lastly, the Ethics Institute of South Africa conducted an online survey in 2014, including South Africa and 14 other countries, with the aim of grasping how Africans perceive Chinese business in Africa. However, the online questionnaire and its diffusion resulted in a sample that was far from nationally representative (Rossouw, Geerts, \& Xinwa, 2014).

This article seeks to further build upon these existing studies of public opinion regarding foreign policy, by zooming in on the specific issue of China as a new partner for the country. It presents more recent data, and brings in a comparative perspective by contrasting South African public opinion with that in other African countries. It also introduces a longitudinal dimension, to see how perceptions of the different international partners have changed over time.

\section{Data sources and sampling procedures}

Unless indicated otherwise, the data presented below was taken from Round 6 of the Afrobarometer. Interviews for Round 6 took place in 2014-2015; the interviews with South African respondents were conducted between 13 August and 21 September 2015. A total of 53,932 respondents were interviewed in 36 African countries ${ }^{1} ; 2,388$ respondents were interviewed in South Africa. 
AFRICAN

EAST-ASIAN

AFFAIRS

The Afrobarometer uses sampling procedures that are 'designed to generate a sample that is a representative cross-section of all citizens of voting age in a given country' (Afrobarometer Network, 2016). The sample is first stratified on the basis of the most important subnational unit in the country (for example, region or province) and by urban or rural location. A multi-stage sampling procedure is then used to select individuals, with random sampling at each stage. Sampling is based on probability proportionate to population size, to ensure that 'every adult citizen has an equal and known chance of being selected for an interview'. The table below shows key demographic characteristics of the South African sample for Round 6 of the Afrobarometer.

Table 1. Characteristics of South African respondents in Afrobarometer Round 6

\begin{tabular}{|c|c|c|c|c|c|}
\hline Gender & Age & Urban / rural & Race & Province & Language \\
\hline $\begin{array}{l}49.9 \% \text { male } \\
51.1 \% \text { female }\end{array}$ & $\begin{array}{l}32.5 \% \text { age } 18-29 \\
45.3 \% \text { age } 30-49 \\
22.2 \% \text { age } 50-\ldots\end{array}$ & $\begin{array}{l}66 \% \text { urban } \\
34 \% \text { rural }\end{array}$ & $\begin{array}{l}75.4 \% \text { black } \\
11.9 \% \text { coloured } \\
9.2 \% \text { white } \\
3.5 \% \text { South Asian } \\
0.1 \% \text { other }\end{array}$ & $\begin{array}{r}12 \% \mathrm{EC} \\
5.4 \% \mathrm{FS} \\
24.8 \% \mathrm{GP} \\
19.6 \% \mathrm{KZN} \\
9.7 \% \mathrm{LP} \\
7.7 \% \mathrm{MP} \\
6.8 \% \mathrm{NW} \\
2.2 \% \mathrm{NC} \\
11.9 \% \mathrm{WC}\end{array}$ & $\begin{array}{l}23.5 \% \text { Zulu } \\
14.2 \% \text { Xhosa } \\
13.7 \% \text { Afrikaans } \\
11.0 \% \text { English } \\
10.3 \% \text { N. Sotho } \\
9.9 \% \text { Tswana } \\
5.5 \% \text { S. Sotho } \\
4.9 \% \text { Tsonga } \\
3.0 \% \text { Swazi } \\
2.3 \% \text { Venda } \\
1.1 \% \text { Ndebele }\end{array}$ \\
\hline
\end{tabular}

Source: Author's own calculations based upon Afrobarometer Network (2015) 


\section{AFRICAN \\ EAST-ASIAN \\ AFFAIRS

\section{Findings}

The findings are presented in two parts. The first focuses on the comparison between public opinion in South Africa on the one hand and in the other African countries surveyed on the other. The second part then looks at differences between key groups within South Africa.

\section{South Africa versus other African countries}

Before going into how South Africans see China and other international partners, it is useful to look at the overall importance that is accorded to China. Do South Africans think China matters to their country? The Afrobarometer results show that this is very much the case. Out of a list of international actors, four out of ten respondents in South Africa chose China as the most influential one. The United States (US), the only other actor to receive a sizable number of responses, follows far behind with 27.4 per cent. This contrasts with the average from the other countries surveyed by the Afrobarometer, where China also emerges as the most influential player but is followed much more closely by both the US and the respective former colonial power. South Africa stands out, therefore, as a country where unique importance is attached to China's influence. This could be related to South Africa's highly-publicised entry into the BRIC(S) grouping in 2010, which brought the relationship with China into the limelight.

Table 2. Influence of international actors

\section{'Which of the following do you think has the most influence on [South Africa], or haven't you heard enough to say?'}

\begin{tabular}{lrr}
\hline Responses & South Africa (\%) & Other countries surveyed (\%) \\
China & 40.1 & 24.9 \\
United States & 27.5 & 23.2 \\
Former colonial power & 7.2 & 22.8 \\
India & 3.3 & 2.1 \\
None of these have much influence & 2.7 & 1.4 \\
\end{tabular}


AFRICAN EAST-ASIAN

\section{AFFAIRS}

\begin{tabular}{lrr} 
International organisations & 1.2 & 5.3 \\
Some other country or organisation & 1.0 & 0.5 \\
South Africa & - & 6.3 \\
France (only asked in Cameroon) & - & 1.5 \\
The UK (only asked in Cameroon) & - & - \\
Missing & - & - \\
No answer & 17.0 & - \\
Don't know & $(2,388)$ & 12.0 \\
\hline (N) &
\end{tabular}

Source: Author's own calculations based upon Afrobarometer Network (2015)

When asked specifically about the influence of China's economic activities on the economy of their country, the results from South Africa are closer to the average from the other African countries. In both cases, around two thirds of people see China as having 'some' or 'a lot' of influence, with most people giving the latter answer. Taken together, these two tables clearly indicate that China is seen as a force to reckon with by South African public opinion.

Table 3. China's economic influence

'How much influence do you think China's economic activities in [South Africa] have on our economy, or haven't you heard enough to say?'

\begin{tabular}{lrr}
\hline Responses & South Africa (\%) & Other countries surveyed (\%) \\
None & 3.7 & 4.5 \\
A little & 11.1 & 12.8 \\
Some & 28.4 & 27.6 \\
A lot & 40.6 & 41.2 \\
Missing & - & 0.1 \\
Don't know & 16.3 & 13.9 \\
\hline (N) & $(2,388)$ & $(50,344)$ \\
\hline
\end{tabular}

Source: Author's own calculations based upon Afrobarometer Network (2015) 


\section{AFRICAN \\ EAST-ASIAN \\ AFFAIRS

This automatically leads to the next question: if China is seen as having major influence on South Africa, is that perceived positively or negatively? Table 4 shows that China's influence is seen as somewhat positive (34.1 per cent) or very positive (16.8 per cent) by over half of the respondents (making for a total of 50.9 per cent). Only 19.8 per cent of respondents expressed a very negative or somewhat negative opinion. While the overall picture is therefore quite positive, it should be noted that South Africans were more critical of China than the average for the other African countries surveyed. Across those countries, 62.5 per cent of respondents saw China's influence positively, and 15.3 per cent saw it negatively.

Table 4. China's influence as positive or negative

\begin{tabular}{|c|c|c|}
\hline Responses & South Africa (\%) & All African countries surveyed (\%) \\
\hline Very negative & 8.6 & 6.5 \\
\hline Somewhat negative & 11.2 & 8.8 \\
\hline Neither positive nor negative & 12.5 & 7.4 \\
\hline Somewhat positive & 34.1 & 35.2 \\
\hline Very positive & 16.8 & 27.3 \\
\hline Missing & - & 0.1 \\
\hline Don't know & 16.8 & 14.7 \\
\hline (N) & $(2,388)$ & $(50,344)$ \\
\hline
\end{tabular}

Source: Author's own calculations based upon Afrobarometer Network (2015)

What are, then, the reasons for perceiving China's influence positively or negatively? Tables 5 and 6 show that these are strongly dominated by domestic economic concerns, both in South Africa and in the other African countries surveyed. Contributing most strongly to positive images of China in South Africa are China's business 
AFRICAN

EAST-ASIAN

AFFAIRS

investment and the cost of Chinese products. Looking at the averages for the other countries surveyed, however, China's investment in infrastructure arises as the key factor creating a positive image. This likely reflects the more advanced economic position of South Africa, where the needs in terms of basic infrastructure support are smaller. It should also be noted that almost a fifth of South African respondents (19.1 per cent) could not indicate which factors contribute to a positive image of China. This is quite a bit more than the average for other African countries, and a similar divergence is apparent in Table 2. One potential explanation is that the Chinese presence is less immediately visible in South Africa, making it more difficult for respondents to think of concrete manifestations.

Interestingly, Chinese products (more specifically their quality) also feature in the first spot of factors contributing to negative images. Ranked second is the perception that China is crowding out local businesses and employment. Two other frequently discussed economic consequences of China's engagement were seen as less important by South African respondents: land grabbing and extraction of resources. The latter did, however, feature more prominently in the responses from the rest of Africa.

Table 5. Reasons for positive image

'Which of the following factors contributes most to positive image of China in [South Africa], or haven't you heard enough to say?'

Responses

China's business investment

The cost of Chinese products

China's investment in infrastructure or other development in the country

China's support for the country in international affairs

None of these

China's policy of non-interference in the internal affairs of African countries
South Africa (\%)

Other countries surveyed (\%)

28.0

16.4

20.9

22.7

12.5

30.7

6.7

5.5

2.4

3.6

4.4 


\section{AFRICAN \\ EAST-ASIAN \\ AFFAIRS

Some other factor

An appreciation of the Chinese people, culture and

Missing

Don't know

Source: Author's own calculations based upon Afrobarometer Network (2015)

Table 6. Reasons for negative image

\begin{tabular}{lrr}
$\begin{array}{l}\text { 'Which of the following factors contributes most to negative images of China in [South Africa], or } \\
\text { haven't you heard enough to say?' }\end{array}$ & & \\
\hline & South Africa (\%) & Other countries surveyed (\%) \\
\hline Responses & 41.6 & 35.7 \\
The quality of Chinese products & 13.7 & 13.7 \\
Chinese economic activities taking jobs or business & & \\
from the locals & 5.7 & 4.1 \\
None of these & 4.9 & 7.3 \\
Land grabbing by Chinese individuals or businesses & 4.9 & 3.9 \\
China's willingness to cooperate with undemocratic & & 5.8 \\
rulers & 4.7 & 10.9 \\
The behaviour of Chinese citizens in the country & 4.2 & 1.1 \\
China's extraction of resources from Africa & 1.7 & - \\
Some other factor & - & 17.5 \\
\hline Missing & 18.6 & $(50,344)$ \\
\hline Don't know & $(2,388)$ & \\
\hline (N) &
\end{tabular}

Source: Author's own calculation based upon Afrobarometer Network (2015) Political factors prove to be far less important in determining images of China, both in South Africa and in the other countries surveyed. Among the factors contributing 
AFRICAN

EAST-ASIAN

AFFAIRS

to positive images, China's support in international affairs was selected by only 6.7 per cent of South African respondents, and non-interference in internal affairs was even less frequently chosen (3.6 percent). In terms of political factors contributing to negative images, only 4.9 per cent of South African respondents chose 'China's willingness to cooperate with undemocratic rulers'. The averages for the other countries surveyed are similar. These results clearly show that public opinion in South Africa, and elsewhere in Africa, is evaluating China's image in terms of its impact on the domestic economy, rather than in terms of abstract political principles.

Building further upon the economic aspects of the relationship with China, respondents were also asked whether China's economic development assistance does a good job of meeting the country's needs. A total of 39.8 per cent of South African respondents said China does a somewhat good job (31.1 per cent) or a very good job ( 8.7 per cent). While this is a larger group than the people saying China does a very bad or a somewhat bad job (24.1 per cent), South Africans do appear to be more sceptical of China than respondents in other African countries. Looking at the averages for the other African countries surveyed, 54.7 opted for 'good job' versus 19.7 per cent for 'bad job'. The difference is especially striking when looking at the 'very good job' answer, which is the least popular answer in South Africa and the second most popular one in the rest of Africa.

Table 7. China's economic development assistance

'In your opinion, does China's economic development assistance to [South Africa] do a good job or a bad job of meeting the country's needs, or haven't you heard enough to say?'

Responses

Very bad job

Somewhat bad job

Neither good nor bad job
South Africa (\%)

Other countries surveyed (\%)

9.8

7.6

14.3

12.1

17.9

(C) Centre for Chinese Studies, Stellenbosch University

All Rights Reserved. 


\begin{tabular}{|c|c|c|c|}
\hline $\begin{array}{c}\text { AFRICAN } \\
\text { EAST-ASIAN } \\
\text { AFFAIRS }\end{array}$ & \multicolumn{3}{|l|}{$\begin{array}{l}\text { Issue } 3 \\
\text { December } 2016\end{array}$} \\
\hline THE CHINA MONITOR & & & \\
\hline \multicolumn{2}{|c|}{ Somewhat good job } & 31.1 & 33.4 \\
\hline \multicolumn{2}{|l|}{ Very good job } & 8.7 & 21.3 \\
\hline \multicolumn{2}{|c|}{$\begin{array}{l}\text { China doesn't give development assistance to the } \\
\text { country }\end{array}$} & 2.5 & 1.4 \\
\hline \multicolumn{2}{|l|}{ Refused } & 0.1 & 0 \\
\hline \multicolumn{2}{|l|}{ Don't know } & 15.6 & 15.8 \\
\hline \multicolumn{2}{|l|}{$(\mathrm{N})$} & $(2,388)$ & $(50,344)$ \\
\hline
\end{tabular}

Source: Author's own calculations based upon Afrobarometer Network (2015)

The results in Table 7 cannot, however, tell us anything about how China scores compared to other development partners. Wave 4 of the Afrobarometer (2008) asked a similar question that allows for comparison with other international players, though it should be kept in mind that these figures date back eight years. Respondents were asked to rate how much each of a set of international actors does to help their country. They could choose from the following responses: 'do nothing, no help', 'help a little bit', 'help somewhat', and 'help a lot'. Table 8 shows which percentage of respondents chose 'helps a lot' for each of the international partners, broken down per African country that was surveyed. The numbers in brackets indicate for each African country which international actor received the highest proportion of 'helps a lot' answers, which actor the second highest proportion, etc. 


\begin{tabular}{|c|r} 
AFRICAN & $\begin{array}{r}\text { Floor Keuleers } \\
\text { EAST-ASIAN } \\
\text { AFFAIRS }\end{array}$ \\
\hline THE CHINA MONITOR & "Which lodestar to follow? South African public opinion on China and other international \\
partners
\end{tabular}

Table 8. How much do external actors do to help

\begin{tabular}{|c|c|c|c|c|c|c|c|c|}
\hline \multicolumn{9}{|c|}{$\begin{array}{l}\text { 'In your opinion, how much do each of the following do to help your country, or haven't you heard enough } \\
\text { to say?' (\% of respondents in each country that answered 'helps a lot') }\end{array}$} \\
\hline \multirow[b]{2}{*}{ Benin } & \multicolumn{2}{|c|}{ China } & \multicolumn{2}{|l|}{ us } & \multicolumn{2}{|c|}{$\begin{array}{l}\text { Former } \\
\text { colonial power }\end{array}$} & \multicolumn{2}{|l|}{ EU } \\
\hline & 29.8 & (1) & 25.60 & (3) & 26.0 & (2) & 20.2 & (4) \\
\hline Botswana & 42.2 & (1) & 40.30 & (2) & 35.4 & (3) & 30.6 & (4) \\
\hline Burkina Faso & 40.1 & (2) & 40.80 & (1) & 36.8 & (3) & 34.6 & (4) \\
\hline Cape Verde & 28.6 & (2) & 31.20 & (1) & 25.8 & (3) & 23.7 & (4) \\
\hline Ghana & 24.1 & (3) & 46.30 & (1) & 35.8 & (2) & 1 & 1 \\
\hline Kenya & 17.4 & (4) & 37.00 & (1) & 28.3 & (2) & 27.7 & (3) \\
\hline Lesotho & 59.3 & (1) & 58.80 & (2) & 47.5 & (3) & 39.3 & (4) \\
\hline Liberia & 48.8 & (2) & 67.00 & (1) & 1 & 1 & 46.5 & (3) \\
\hline Madagascar & 11.0 & (4) & 16.40 & (2) & 17.3 & (1) & 15.7 & (3) \\
\hline Malawi & 21.8 & (4) & 23.70 & (3) & 25.5 & (1) & 24.4 & (2) \\
\hline Mali & 47.4 & (1) & 43.10 & (2) & 38.1 & (3) & 27.9 & (4) \\
\hline Mozambique & 32.3 & (1) & 31.70 & (2) & 20.9 & (4) & 26.8 & (3) \\
\hline Namibia & 24.3 & (4) & 34.80 & (1) & 27.8 & (2) & 26.4 & (3) \\
\hline Nigeria & 13.3 & (4) & 17.90 & (1) & 14.1 & (2) & 14.0 & (3) \\
\hline Senegal & 33.3 & (1) & 23.70 & (3) & 26.9 & (2) & 20.5 & (4) \\
\hline South Africa & 8.3 & (4) & 9.7 & (1) & 8.5 & (3) & 9.5 & (2) \\
\hline Tanzania & 15.6 & (4) & 41.50 & (1) & 28.5 & (2) & 24.0 & (3) \\
\hline Uganda & 6.2 & (4) & 23.30 & (1) & 20.0 & (2) & 19.8 & (3) \\
\hline Zambia & 34.3 & (1) & 33.80 & (2) & 23.8 & (3) & 22.8 & (4) \\
\hline Zimbabwe & 21.2 & (2) & 31.90 & (1) & 18.8 & (3) & 15.0 & (4) \\
\hline Total & 25.5 & (2) & 31.6 & (1) & 23.8 & (3) & 22.3 & (4) \\
\hline
\end{tabular}

Source: Author's own calculations based upon Afrobarometer Network (2014) 


\section{AFRICAN \\ EAST-ASIAN \\ AFFAIRS

The first finding is that more South African respondents chose 'helps a lot' for the US, the European Union (EU) and the former colonial power than was the case for China. The differences are very small, however, and South Africa mainly stands out as a country that is very critical of all outside help. The scores are generally much higher in the other countries surveyed. This is in line with the findings in Table 4 and Table 7 -where South Africans were also found to be more sceptical- and it raises the question of why this is the case. While one can speculate about the role of South Africa's complex historical relations, its vibrant and open domestic debate, or the fact that it is not an aid-dependent country, more in-depth research is needed to confirm any of these explanations.

The position of China varies in the other African countries surveyed, from being the most appreciated (according to this specific measure at least) partner in Benin, Botswana, Lesotho, Mali, Mozambique and Zambia, to being the last ranked in Kenya, Madagascar, Malawi, Namibia, Nigeria, Tanzania and Uganda. Another observation from these figures is that the EU does not score very strongly, with not a single country surveyed ranking it first.

Returning to the 2015 wave of the Afrobarometer, it is interesting to analyse how China is evaluated as a model for development and how this compares to other potential models. While the ANC may describe China as a lodestar, it appears South African public opinion is still very much oriented towards the US as a model for development (36 per cent). China follows in second place, but with a considerably lower score (26.1 per cent). The order is the same when looking at the averages for the other African countries surveyed, but here China follows the US' lead more closely. $^{2}$

Table 9. Best model for future development

'In your opinion, which of the following countries, if any, would be the best model for the future development of our country?'

Responses

United States

China
South Africa (\%)

36.0

26.1
Other countries surveyed (\%)

30.8

24.2

(C) Centre for Chinese Studies, Stellenbosch University

All Rights Reserved. 
AFRICAN

EAST-ASIAN

AFFAIRS
Former colonial power

We should follow our own country's model

None of these

India

Other

South Africa

Don't know

(N)
11.7

8.3

2.4

2.0

0.6

12.9

9.2

12.6

5.0

1.8

2.3

$(2,388)$

$(51,544)$

Source: Author's own calculation based upon Afrobarometer Network (2015)

The figures presented so far only give snapshots of a particular point in time. This raises the question of how China's image has evolved over recent years. Is (presumably) increasing familiarity with China's presence making China more popular in South Africa, or less? And how are other international actors faring? Unfortunately, no longitudinal data is available for the above questions from the Afrobarometer, as different questions tend to be asked in each round. We briefly turn, therefore, to data from the Global Attitudes \& Trends Surveys of the Pew Research Center. While its recurring questions are more general in nature, they do allow for comparison over time. The figure below is based upon the question 'Please tell me if you have a very favorable, somewhat favorable, somewhat unfavorable, or very unfavorable opinion of [China]'. It should be kept in mind that given its general wording, responses to this question can be driven by a variety of considerations, including the actor's relationship with South Africa (as in Table 8), but also the actor's domestic system or its policies towards other parts of the world. 


\begin{tabular}{|c|} 
AFRICAN \\
EAST-ASIAN \\
AFFAIRS \\
\hline THE CHINA MONITOR \\
\hline
\end{tabular}

Figure 1. Favourable opinions of international actors

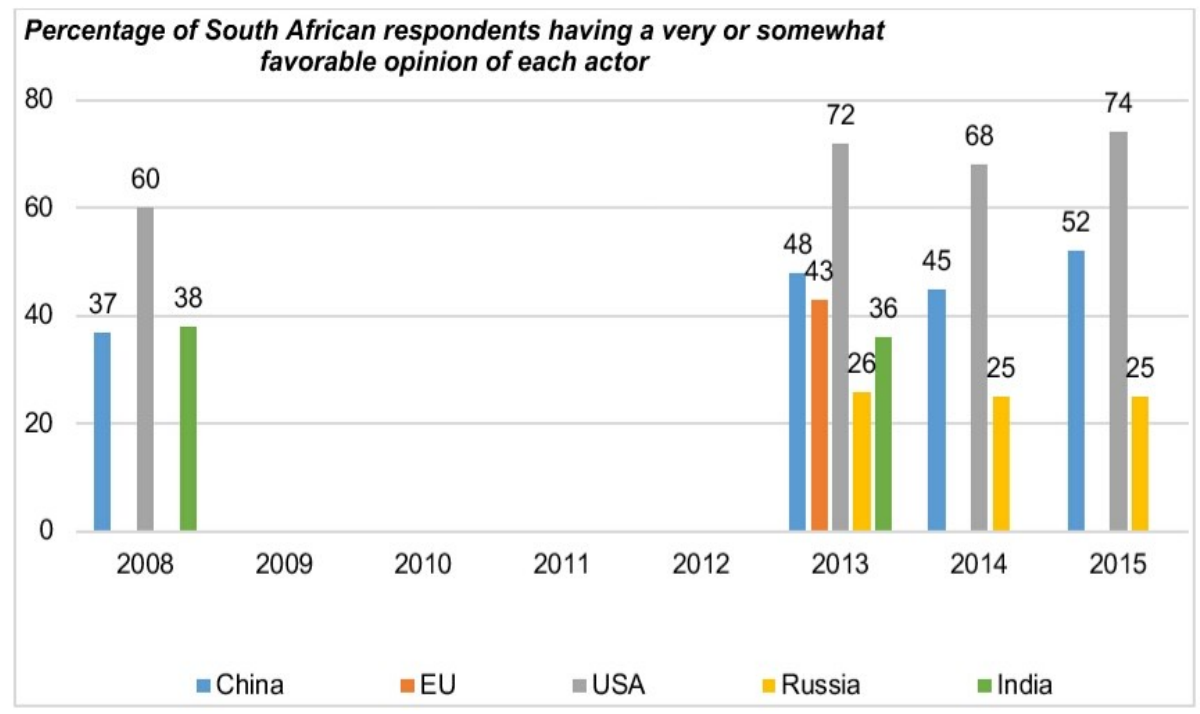

Source: Author's own calculations based upon Pew Research Center (2008, 2013, 2014, 2015)

Figure 1 shows that while there are some fluctuations in the scores, the ranking of the different international actors appears to be quite stable over time. The US consistently scores best, with China usually ranking second. There does not appear to be support for the claim that China's image has deteriorated over time as the (negative) impacts of its engagement became clearer.

\section{Differences within South Africa}

Lastly, we ask how views differ between different groups within South Africa. For this purpose, we take another look at two of the questions discussed above: one China-focused question (is China's influence positive or negative) and one question that allows for comparison with other international partners (which country is the best model). We also include a third question, which was not yet discussed since it was 
AFRICAN

EAST-ASIAN

AFFAIRS

only asked in South Africa. This question is specifically focused on foreign policy, asking respondents which countries South Africa should prioritise in her international relationships.

We zoom in on three key demographic variables. ${ }^{3}$ The first one is age. The reason why age might be interesting is that South Africa's relationship with China (at least in its current form) is a relatively recent one, compared to the more longstanding ties with Europe and the US. Do young South Africans, who have grown up in this new context, regard China differently than older sections of South African public opinion? The second variable is race. We follow the stance taken by Van der Westhuizen and Smith, who have argued that while racial categories as employed in surveys are inadequate to capture a much more complex social reality, race is still a very pervasive feature of South African society (Van der Westhuizen \& Smith, 2015). It is interesting to see, therefore, to what extent appraisals of China and of other international partners are shared by different groups in society. The last variable is respondents' party preference, as expressed by their answer to the question 'If presidential elections were held tomorrow, which party's candidate would you vote for?'. Does party preference correspond with a different perception of China and other international partners? Table 10 presents the results.

The first observation is that age does appear to play a role. The proportion of respondents evaluating China's influence as somewhat positively or very positively declines with age. Respondent over fifty are most likely to evaluate China's influence negatively (20.9 per cent), although the difference with those aged between 30 and 49 is very small (20.5 per cent). When asked which country would be the best model for the future development of South Africa, all age categories agree that the US is the preferred model and that China is the second-best option. In addition, respondents over fifty seem more hesitant about the idea of another country figuring as a model for South Africa; they are more likely to say 'we should follow our own country's model', 'I don't know', or 'none of these'. When asked which countries South Africa should prioritise in her international relationships, respondents from all age groups are most likely to say 'developed countries', followed by 'BRIC coun- 


\section{AFRICAN \\ EAST-ASIAN \\ AFFAIRS \\ THE CHINA MONITOR}

tries'. Older respondents, however, are somewhat more likely than younger ones to opt for 'neighbouring countries' or 'all African countries'.

When the figures are broken down according to race, it is clear that across groups, the answer that 'China's influence is somewhat positive' is the most popular one. Coloured and South Asian respondents have the largest positive perception of China's influence (both 55.4 per cent positive), while white South Africans have the smallest proportion with a positive perception ( 44.8 per cent positive). Interestingly, South Asian respondents also have the largest proportion with a negative perception of China's influence (28.9 per cent). This reflects the fact that no South Asian respondents answered 'I don't know', making them a very outspoken group. White South Africans have the second largest proportion of negative perceptions of China, standing at 26.5 per cent. When asked which country is the best model, there is again agreement on the US as the number one choice. While China is the second-most popular choice among black and coloured respondents, the United Kingdom (UK) occupies this spot among white and South Asian respondents. When asked who South Africa should prioritise in its international relations, the differences between groups are quite outspoken. Among black respondents, identical proportions chose 'developed countries' and 'BRIC countries'. Coloured, South Asian and especially white South Africans, in contrast, are much more likely to say 'developed countries'. White respondents are also less likely to say 'our neighbours' or 'all African countries'.

Lastly, turning to the party preferences ${ }^{4}$ of respondents, there are again some similarities as well as differences between the various groups. Respondents from all three parties are most likely to say that China's influence is 'somewhat positive'. ANC and Economic Freedom Fighters (EFF) voters are relatively more likely to see its influence as very positive, and Democratic Alliance (DA) voters are most likely to see its influence as very negative (11.1 per cent) or somewhat negative (16 per cent). When asked which country is the best model for the future development of South Africa, only EFF voters are most likely to choose China (34.5 per cent). The difference in proportion with EFF voters who prefer the US is, however, very small (33.2 per cent). ANC and DA voters are both most likely to choose the US as the best 
AFRICAN

EAST-ASIAN

AFFAIRS

model and China as the second-best, but China follows much more closely in the case of ANC voters than in the case of DA voters. DA voters are also much more likely than other voters to choose the UK as the best model. A very similar pattern emerges for the last question. EFF voters are again the only ones who are more likely to choose the BRIC countries over developed countries. Among ANC voters, 25.7 per cent choose developed countries and 25.5 per cent choose the BRIC countries. DA voters have the most outspoken preference, with 44.4 per cent wanting South Africa to focus on developed countries in its international relations, versus 17.1 per cent for the BRIC countries. 


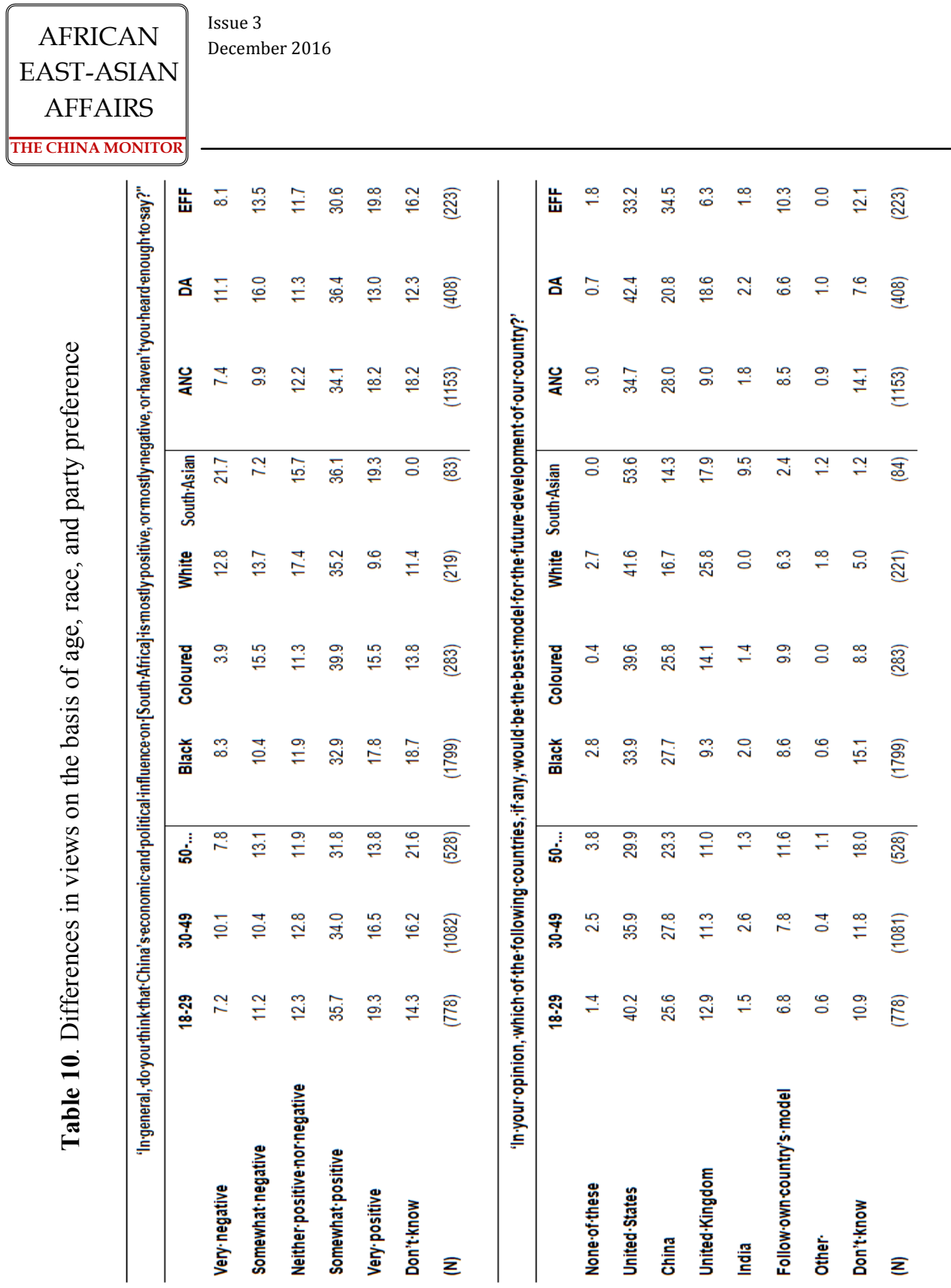

(C) Centre for Chinese Studies, Stellenbosch University All Rights Reserved. 


\section{AFFAIRS}

\section{THE CHINA MONITOR}

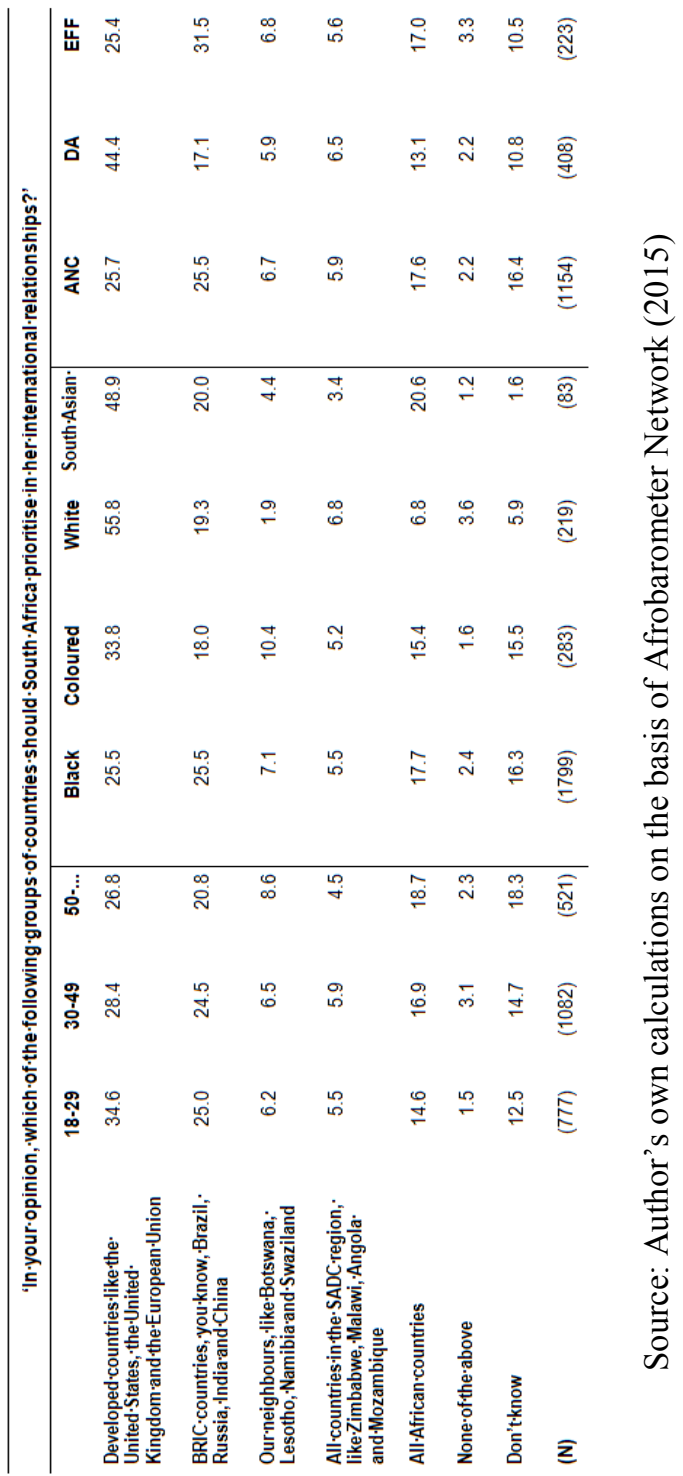

(C) Centre for Chinese Studies, Stellenbosch University All Rights Reserved. 


\section{AFRICAN \\ EAST-ASIAN \\ AFFAIRS

\section{Conclusion}

South Africa's international orientation is said to be shifting, with the post-1994 focus on democracy and human rights increasingly complemented or even replaced by pragmatic relations with fellow BRICS countries. This article asked how ordinary South Africans perceive the different international partners their country might turn to, with a specific focus on evaluations of China. It did so by analysing the 2015 wave of the Afrobarometer Survey, which uses nationally representative samples to grasp the views of citizens across the continent. Two types of comparison were central: between South Africa and other African countries on the one hand, and between different groups within South Africa on the other.

When South Africans were asked which international actor has the most influence on their country, China emerges as the top pick, indicating the perceived importance of the relationship. Positive assessments of China's influence are more prevalent than negative ones, and there is no indication of assessments becoming more negative over time. Economic considerations are very dominant in shaping both positive and negative images of China, with political factors playing a marginal role. Compared to the rest of Africa, South African public opinion stands out as very critical, not only of China but of international partners in general. Infrastructure support and extraction of resources play a more important role in shaping China's image in other African countries than they do in South Africa, which likely reflects differences in economic position and structure. The South African results and the averages for the other African countries both indicate that the US remains very dominant as a model for development, with China coming in second. Looking at differences in views within South Africa, age, race and party preference emerged as key structuring variables. China is seen most positively by young South Africans, coloured and South Asian respondents, and ANC and EFF voters. It should be stressed, however, that South Africans across these lines agree that China's influence is 'somewhat positive' and that the US remains the best model for the future development of their country. 
AFRICAN

EAST-ASIAN

AFFAIRS

To conclude, it should be reiterated that South African public opinion on foreign policy is only starting to be uncovered. On the one hand, there is a need for more survey data, particularly of the kind that makes longitudinal analyses possible. On the other hand, alternative methodologies can be useful to study public opinion in a more flexible way. As Roselle, O'Loughlin, and Miskimmon (2015) have noted: 'here is a recurrent asymmetry in current research: scholars analyse policymakers' narratives and public attitudes. They do not analyse public narratives'. While it is commonly accepted that elites and policymakers make sense of the world through complex stories, public opinion tends to be measured through lists of predetermined questions and highly limited answering options. This leaves little room for respondents to express the motivations behind their responses, whether the questions and statements speak to their own experience, and how their fragmented answers combine into a more holistic outlook on the world. It would therefore be an interesting and complementary approach to also draw on qualitative and more indepth techniques, in order to study how South Africans form their own narratives about the international relations of their country, as it navigates the geopolitical shifts of the $21^{\text {st }}$ century.

\section{Endnotes}

1. Algeria, Botswana, Burundi, Cameroon, Cape Verde, Benin, Gabon, Ghana, Guinea, Côte d'Ivoire, Kenya, Lesotho, Liberia, Madagascar, Malawi, Mali, Mauritius, Morocco, Mozambique, Namibia, Niger, Nigeria, Sao Tome and Principe, Senegal, Sierra Leone, South Africa, Zimbabwe, Sudan, Swaziland, Togo, Tunisia, Uganda, Egypt, Tanzania, Burkina Faso, Zambia.

2. It should be noted that the Afrobarometer presented respondents with a limited list of countries to choose from. The results may have been different if alternative models had been included, for instance the Asian Tigers or European countries other than the former colonial power.

3. During the analysis, it was also checked whether any clear patterns on the basis of gender, employment status, education, and urban/rural location could be observed. This was found not to be the case. The main differences between 


\section{AFRICAN \\ EAST-ASIAN \\ AFFAIRS

groups here tended to be the proportion of respondents answering 'don't know', which was higher among women, those without employment and who were not looking, those with no formal schooling or some primary schooling, and those in rural locations.

4. Due to space limitations, only the results for the three largest parties are presented here. Together these account for 1,785 respondents out of the total of 2,388 (or 74.75 per cent). From the remaining respondents, 133 indicated they would not vote, 260 refused to answer, 67 said 'don't know', and 136 were spread over a large number of smaller parties.

\section{Bibliography}

African National Congress. 2015. 53rd National Conference Discussion Documents. Marshalltown: African National Congress.

Afrobarometer Network. 2014. Afrobarometer Round 4. [Online] Available: http:// afrobarometer.org/data/data-rounds-merged [25 September 2016].

Afrobarometer Network. 2015. Afrobarometer Round 6. [Online] Available: ww.afrobarometer.org [25 September 2016].

Afrobarometer Network. 2016. Sampling principles. [Online] Available: http:// www.afrobarometer.org/surveys-and-methods/sampling-principles September 2016].

Anthony, R., Tembe, P., \& Gull, O. 2015. South Africa's changing foreign policy in a multi-polar world: The influence of China and other emerging powers. Stellenbosch: Centre for Chinese Studies.

Bradley, A. 2016. China and South Africa: Emerging Powers in an Uncomfortable Embrace. Journal of Contemporary China, 25(102): 881-892.

Department of International Relations and Cooperation. 2011. Building a Better World: The Diplomacy of Ubuntu. White Paper on South Africa's Foreign 
AFRICAN

EAST-ASIAN

AFFAIRS

Policy. Pretoria: Department of International Relations and Cooperation.

Hanusch, M. 2012. African Perspectives on China-Africa: Modelling Popular Perceptions and their Economic and Political Determinants. Oxford Development Studies, 40(4): 492-516.

Hartig, F. 2014. The Globalization of Chinese Soft Power: Confucius Institutes in South Africa, in R. S. Zaharna, J. Hubbert \& F. Hartig (eds.). Confucius Institutes and the Globalization of China's Soft Power. Los Angeles: Figueroa Press, 47-60.

Keuleers, F. 2015. Explaining External Perceptions: The EU and China in African Public Opinion. Journal of Common Market Studies, 53(4): 803-821.

King, K. 2013. China's Aid and Soft Power in Africa: The Case of Education and Training. Suffolk and Rochester: James Currey.

Landsberg, C. 2014. The Concentric Circles of South Africa's Foreign Policy under Jacob Zuma. India Quarterly, 70(2): 153-172.

Nel, P. 1999. The Foreign Policy Beliefs of South Africans: A First Cut. Journal of Contemporary African Studies, 17(1): 123-146.

Park, Y. J. 2013. Perceptions of Chinese in Southern Africa: Constructions of the "Other" and the Role of Memory. African Studies Review, 56(1): 131-153.

Pew Research Center. 2008. Global Attitudes \& Trends Spring 2008 Survey Data. [Online] Available: http://www.pewglobal.org/category/datasets/? download=12022 [25 September 2016].

Pew Research Center. 2013. Global Attitudes \& Trends Spring 2013 Survey Data. [Online] Available: http://www.pewglobal.org/category/datasets/? download=31111 [25 September 2016].

Pew Research Center. 2014. Global Attitudes \& Trends Spring 2014 Survey Data. [Online] Available: http://www.pewglobal.org/category/datasets/2014/? download=35293 [25 September 2016]. 


\section{AFRICAN \\ EAST-ASIAN \\ AFFAIRS

Pew Research Center. 2015. Global Attitudes \& Trends Spring 2015 Survey Data. [Online] Available: http://www.pewglobal.org/category/datasets/2015/ [25 September 2016].

Roberts, B. J., Struwig, J., Gordon, S., \& Bohler-Muller, N. 2015. Contemporary South African foreign policy: Public knowledge, beliefs and preferences. HSRC Policy Brief Series 2014/15(13). Cape Town: Human Sciences Research Council Press.

Roselle, L., O'Loughlin, B., \& Miskimmon, A. 2015. Public Narratives about Syria: A Q-Sort Analysis of UK and US Students. Paper presented at the International Studies Association (ISA) Annual Convention, 18-21 February, New Orleans.

Rossouw, G., Geerts, S., \& Xinwa, N. 2014. Africans' perception of Chinese Business in Africa: A Survey. Research Report. Pretoria: Ethics Institute of South Africa.

Sautman, B., \& Yan, H. 2009. African Perspectives on China-Africa Links. The China Quarterly, 199(September): 728-759.

Van der Westhuizen, J., \& Smith, K. 2015. Pragmatic internationalism: public opinion on South Africa's role in the world. Journal of Contemporary African Studies, 33(3): 318-347.

Wasserman, H. 2015. China's "soft power" and its influence on editorial agendas in South Africa. Chinese Journal of Communication, 9(1): 8-20.

Wu, Y.-S. 2012. The Rise of China's State-Led Media Dynasty in Africa. Occasional Paper No 117. Johannesburg: South African Institute of International Affairs. 
